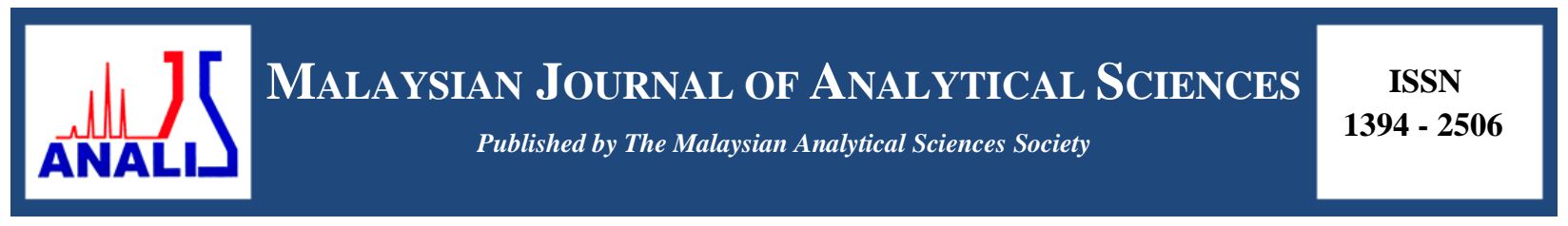

\title{
SYNTHESIS OF 2-AMINOBIARYL DERIVATIVES PROMOTED BY WATER EXTRACT OF ONION PEEL ASH
}

\section{(Sintesis Terbitan 2-Aminobiaril Dimangkinkan oleh Ekstrak Air Abu Kulit Bawang)}

\author{
Poh Wai Chia ${ }^{1,2}$, Poh Seng Chee ${ }^{1}$, Siti Nur Aqlili Riana Mohd Asseri ${ }^{1}$, Fu Siong Julius Yong ${ }^{2}$, Su-Yin Kan ${ }^{3}$ \\ ${ }^{I}$ School of Marine and Environmental Sciences \\ ${ }^{2}$ Institute of Marine Biotechnology \\ Universiti Malaysia Terengganu, 21030 Kuala Nerus, Terengganu, Malaysia \\ ${ }^{3}$ Faculty of Health Sciences, \\ Universiti Sultan Zainal Abidin, 21300 Kuala Nerus, Terengganu, Malaysia \\ *Corresponding author: pohwai@umt.edu.my
}

Received: 17 March 2018; Accepted: 2 July 2018

\begin{abstract}
The biaryl and its derivatives are important organic compounds that possess various interesting applications, such as in the field of medicine, organic-light emitting materials, agrochemicals and other functional properties. Traditionally, radical arylation of arylhydrazines and anilines requires the use of metals, excess of base, flammable solvent and so on. Thus, a greener catalytic system for the synthesis of 2-aminobiaryls is highly sought after. In this work, a recyclable catalytic media has been developed for the synthesis of 2-aminobiaryl derivatives via a direct arylation of anilines with arylhydrazines in the presence of water extract of the burned-ash of onion peel waste (ash-water extract). This method provides numerous advantages, such as external base- and metal-free, recyclable catalytic system, inexpensive and the products were achieved in moderate to good yield. This sustainable synthesis is scientifically important, as it is capable of minimizing the use of toxic reagents and at the same time offers an alternative method to manage the abundant bio-waste.
\end{abstract}

Keywords: ash-water extract, 2-aminobiaryls, recyclable catalytic system, arylhydrazine, aniline

\begin{abstract}
Abstrak
Biaril dan derivatifnya adalah sebatian organik yang penting dan didapati memiliki pelbagai aplikasi menarik, seperti dalam bidang perubatan, bahan pemancar cahaya organik, agrokimia dan sifat-sifat lain. Secara tradisional, arilasi radikal yang melibatkan arilhidrazin dan anilin memerlukan penggunaan logam, bes lebihan, pelarut mudah terbakar dan sebagainya. Oleh itu, sistem pemangkin yang lebih hijau untuk sintesis 2-aminobiaril sangat diperlukan. Dalam kerja ini, media pemangkin yang boleh dikitar semula telah dibangunkan untuk sintesis terbitan 2-aminobiaril melalui arilasi anilin dengan arilhidrazin dalam kehadiran ekstrak air abu bawang merah (ekstrak air-abu). Kaedah ini memberi pelbagai kelebihan termasuk mengelakkan penggunaan bes luaran, bebas logam, sistem pemangkin yang boleh dikitar semula, murah dan kuantiti produk yang dihasilkan dalam lingkungan sederhana hingga baik. Sintesis lestari ini adalah penting secara saintifik, kerana ia mampu meminimalkan penggunaan reagen beracun dan pada masa yang sama menawarkan satu kaedah alternatif untuk menguruskan sisa biologi.
\end{abstract}

Kata kunci: ekstrak air-abu, 2-aminobiaril, media pemangkin boleh kitar semula, arilhidrazin, anilin

\section{Introduction}

In recent years, much attention has been devoted in both the industrial and academic communities to develop simple yet efficient green procedures in organic syntheses due to increasing environmental concern $[1,2]$. The encouraging 
use of environmentally acceptable chemicals, solvents and catalysts in recent times is scientifically significant to achieve both sustainable chemistry for synthesis and industrialization [3]. To that end, aqueous media have been highly regarded as a green solvent and has attracted the attention of the scientific community as they are environmentally friendly, inexpensive, non-toxic, have large dielectric constant, non-flammable and readily available, which are all desirable attributes in synthetic chemistry $[4,5]$. Apart from meeting the benchmark of green chemistry, the use of water as solvent in organic synthesis has gained reputation as a catalyst [6-9].

The use of waste water, water extracts of fruits and vegetables juices have recently been reported to address and apply the concept of green chemistry in performing organic chemical processes [10]. Reactions promoted by these green catalytic systems and also other green media which utilize water as solvents are scientifically significant because of their biodegradable/recyclable nature and high solvating ability. As a result, the green aspect and recyclability of these non-classical solvents have been utilized in versatile organic reactions, such as the SuzukiMiyaura reaction [11], Sonogashira reaction [12], green synthesis of 3-carboxycoumarins [13], Henry reaction [14] or Dakin reaction [15]. Bio-wastes are attractive resources from the perspective of green chemistry to achieve green chemical processes. According to a survey, the food processing factories and eateries generate millions of tonnes of bio-wastes monthly [16]. Furthermore, the amount of bio-wastes are expected to increase over time due to the increasing world population [17].

Onions (Allium cepa L.) are considered as one of the important vegetable crops grown globally for culinary, nutritional and other functional purposes [18]. Research has shown that more than 100,000 tonnes of onion wastes are generated annually from the United States of America and European countries [19]. These bio-wastes are disposed directly to the landfill which has seriously impacted our environment, wildlife and the human health [20]. In our continuous effort for developing new synthetic methodologies, herein we would like to report on a simple, and efficient procedure of synthesizing 2-aminobiaryls in the presence of a recyclable catalytic medium- Water Extract of Onion Peel Ash (WEOPA) (Scheme 1). The biaryls are important building blocks in various fields of application, such as drugs [21], organic chromophores [22], agrochemicals and other functional compounds [23]. In general, radical arylation involving the arylhydrazines and anilines required the use of metal [24], an excess of base [25], flammable solvent [26] and so on. The current work which employed the WEOPA catalytic system to facilitate the synthesis of 2-aminobiaryls is capable to reduce the environmental pressure by using environmental benign natural feedstock extract from waste onion peel and at the same time overcome the above mentioned drawbacks.

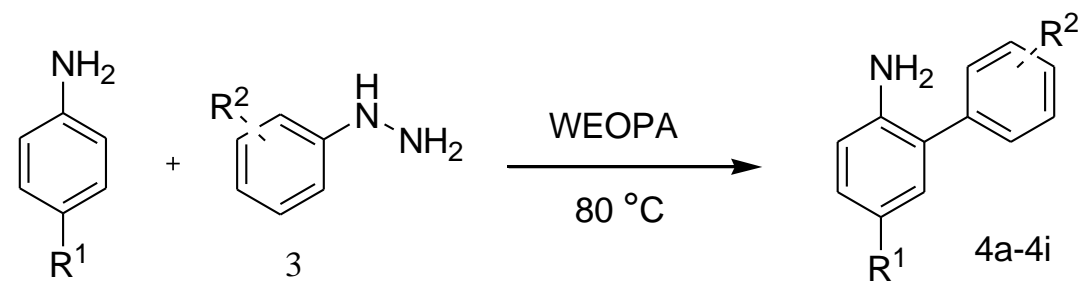

$\mathrm{R}^{1}=\mathrm{F}(1)$, ethyl (2)

Scheme 1. Synthesis of 2-aminobiaryls in the presence of WEOPA

\section{Materials and Methods}

All reagents and chemicals used in this research including ethyl acetate, 4-chlorophenylhydrazine, 3-bromo phenylhydrazine, 3-fluorophenylhydrazine, 4-fluorophenylhydrazine, 4-bromophenylhydrazine, 3-chlorophenyl hydrazine, 4-fluoroaniline, 4-ethylaniline, chloroform-d $\left(\mathrm{CDCl}_{3}\right)$ and silica gel $60(0.063-0.200 \mathrm{~mm})$ were purchased from Sigma-Aldrich and used without further purification. ${ }^{1} \mathrm{H}$ and ${ }^{13} \mathrm{C}$-NMR spectra were recorded in $\mathrm{CDCl}_{3}$ solvent on Bruker Avance III 400 spectrometer and chemical shifts were given in parts per million (ppm). The GC-MS spectra were recorded on a Shimadzu QP2010SE equipped with a Supelco fused silica capillary column (30 $\mathrm{m} \times 0.25 \mathrm{~mm}$ i.d., $0.25 \mathrm{~mm}$ film thickness). The total carbon, hydrogen, nitrogen and sulphur (CHNS) of products was determined with a CHNS Analyser Flashea 1112 series. The FT-IR spectra were recorded using a 
Perkin Elmer Spectrum 100 FT-IR Spectrometer. The metal content was studied using Varian Vista Pro inductive coupled plasma-optical emission spectroscopy (ICP-OES). The metal content analysis on ash-water extract was carried out in triplicates and the values were given as (mean \pm standard deviation), in parts per billion (ppb).

\section{Preparation of the water extract of onion peel ash (WEOPA)}

The onion waste was sampled from a local disposal site in Kuala Terengganu, Malaysia in March 2018. The outer layer of onion peel was separated from the bulb, cleaned and washed twice with distilled water. Subsequently, the onion peels were cut into small pieces and sun-dried for two days. The WEOPA was prepared according to the method described by Boruah et al. [11]. Firstly, $2.5 \mathrm{~g}$ of dried peels were subjected to furnace at $500{ }^{\circ} \mathrm{C}$ for 1 hour. The resulted ash was collected and transferred to a $100 \mathrm{~mL}$ conical flask suspended with $30 \mathrm{~mL}$ of distilled water with continuous stirring for 1 hour. The mixture was filtered and the filtrate was termed as WEOPA.

\section{Synthesis procedure for 2 -aminobiaryls $4 a-4 i$.}

WEOPA ( $2 \mathrm{~mL})$ was added into a $25 \mathrm{~mL}$ sample vial that was suspended with a mixture of anilines $(1.00 \mathrm{mmol})$ and arylhydrazines $(1.00 \mathrm{mmol})$. The reaction mixture was left for continuous stirring at $80{ }^{\circ} \mathrm{C}$. The progress of the reaction was monitored by thin-layer chromatography (TLC). After the completion of the reaction, the aqueous layer was extracted with ethyl acetate $(3 \times 10 \mathrm{~mL})$. The organic layer was subjected to silica gel column purification with ethyl acetate/hexane (1:9) as eluent. The aqueous WEOPA that was recovered was reused for the synthesis of other 2-aminobiaryls under the same condition.

\section{Spectroscopic data of 2-aminobiaryls}

\section{Results and Discussion}

3'-Chloro-5-fluoro-biphenyl-2-ylamine 4a ${ }^{1} \mathrm{H}-\mathrm{NMR}\left(400 \mathrm{MHz}, \mathrm{CDCl}_{3}\right): \delta 3.62$ (brs, $\left.2 \mathrm{H}\right) ; 6.69$ (dd, $J=4.9 \mathrm{~Hz}, J=$ $8.7 \mathrm{~Hz}, 1 \mathrm{H}) ; 6.84(\mathrm{dd}, J=3.2 \mathrm{~Hz}, J=9.2 \mathrm{~Hz}, 1 \mathrm{H}) ; 6.85(\mathrm{~m}, 1 \mathrm{H}) ; 7.32-7.45(\mathrm{~m}, 4 \mathrm{H}) \mathrm{ppm} ;{ }^{13} \mathrm{C}$ NMR $(100 \mathrm{MHz}$, $\left.\mathrm{CDCl}_{3}\right) \delta 115.36,115.58,116.42,116.64,116.72,126.99,127.77,129.07,130.20,134.79,139.52,140.37,155.01$, 157.44 ppm; GC-MS: $\mathrm{C}_{12} \mathrm{H}_{9} \mathrm{ClFN}, \mathrm{m} / \mathrm{z} 221.05(\mathrm{M})^{+}$. Anal. calcd for $\mathrm{C}_{12} \mathrm{H}_{9} \mathrm{ClFN}$ : C 65.02, H 4.09, N 6.32; found C $65.00, \mathrm{H} 4.02, \mathrm{~N} 6.29$.

3'-Bromo-5-fluoro-biphenyl-2-ylamine 4b ${ }^{1} \mathrm{H}-\mathrm{NMR}\left(400 \mathrm{MHz}, \mathrm{CDCl}_{3}\right)$ : $\delta 3.63$ (brs, $\left.2 \mathrm{H}\right) ; 6.70$ (dd, $J=4.9 \mathrm{~Hz}, J=$ $8.3 \mathrm{~Hz}, 1 \mathrm{H}) ; 6.82(\mathrm{dd}, J=2.8 \mathrm{~Hz}, \mathrm{~J}=9.1 \mathrm{~Hz}, 1 \mathrm{H}) ; 6.88(\mathrm{~m}, 1 \mathrm{H}) ; 7.26-7.59(\mathrm{~m}, 4 \mathrm{H}) \mathrm{ppm} ;{ }^{13} \mathrm{C}$ NMR $(100 \mathrm{MHz}$, $\left.\mathrm{CDCl}_{3}\right) \delta 115.39,115.66,116.53,123.00,127.59,130.45,130.77,132.01,139.51,140.59,155.15,157.42 \mathrm{ppm}$; GC-MS: $\mathrm{C}_{12} \mathrm{H}_{9} \mathrm{BrFN}, \mathrm{m} / \mathrm{z} 264.95(\mathrm{M})^{+}$. Anal. calcd for $\mathrm{C}_{12} \mathrm{H}_{9} \mathrm{BrFN}$ : C 54.16, H 3.41, N 5.26; found C 54.11, H 3.39, N 5.25.

3'-Fluoro-5-fluoro-biphenyl-2-ylamine 4c ${ }^{1} \mathrm{H}-\mathrm{NMR}\left(400 \mathrm{MHz}, \mathrm{CDCl}_{3}\right): \delta 4.65$ (brs, $\left.2 \mathrm{H}\right) ; 6.66$ (dd, $J=4.8 \mathrm{~Hz}, J=$ 8.6 Hz, 1H); 6.73-6.81 (m, 2H); 6.95-7.00 (m, 1H); 7.07-7.09 (m, 1H); 7.15-7.16 (m, 1H); 7.32-7.38 (m, 1H) ppm; ${ }^{13} \mathrm{C}$ NMR $\left(100 \mathrm{MHz}, \mathrm{CDCl}_{3}\right) \delta 113.31,113.53,114.43,115.21,115.44,115.71,115.78,123.67,123.68,125.95$, $129.52,129.61,139.01,139.02,139.90,139.97,153.91,156.25,166.79,163.24 \mathrm{ppm} ; \mathrm{GC}-\mathrm{MS}: \mathrm{C}_{12} \mathrm{H}_{9} \mathrm{~F}_{2} \mathrm{~N}, \mathrm{~m} / \mathrm{z}$ $205.05(\mathrm{M})^{+}$. Anal. calcd for $\mathrm{C}_{12} \mathrm{H}_{9} \mathrm{~F}_{2} \mathrm{~N}$ : C 70.24, H 4.42, N 6.83; found C 70.21, H 4.39, N 6.80.

4'-Fluoro-5-fluoro-biphenyl-2-ylamine 4d ${ }^{1} \mathrm{H}-\mathrm{NMR}\left(400 \mathrm{MHz}, \mathrm{CDCl}_{3}\right): \delta 3.58$ (brs, $\left.2 \mathrm{H}\right) ; 6.69$ (dd, $J=4.6 \mathrm{~Hz}, J=$ 8.6 Hz, 1H); 6.81-6.90 (m, 2H); 7.12-7.16 (m, 2H); 7.39-7.42 (m, 2H) ppm; ${ }^{13} \mathrm{C}$ NMR $\left(100 \mathrm{MHz}, \mathrm{CDCl}_{3}\right) \delta 114.93$, $115.15,115.77,115.98,116.48,116.56,116.78,127.56,127.63,130.62,130.70,134.43,134.45,139.66,139.92$, 155.11, 157.47, 161.01, 163.47 ppm; GC-MS: $\mathrm{C}_{12} \mathrm{H}_{9} \mathrm{~F}_{2} \mathrm{~N}, \mathrm{~m} / \mathrm{z} 205.05(\mathrm{M})^{+}$. Anal. calcd for $\mathrm{C}_{12} \mathrm{H}_{9} \mathrm{~F}_{2} \mathrm{~N}$ : C 70.24, $\mathrm{H}$ 4.42, N 6.83; found C 70.22, H 4.38, N 6.81.

4'-Bromo-5-fluoro-biphenyl-2-ylamine 4e ${ }^{1} \mathrm{H}-\mathrm{NMR}\left(400 \mathrm{MHz}, \mathrm{CDCl}_{3}\right): \delta 3.76$ (brs, $\left.2 \mathrm{H}\right) ; 6.71$ (dd, $J=4.9 \mathrm{~Hz}, J=$ 8.7 Hz, 1H); 6.82-6.91 (m, 2H); 7.31-7.33 (m, 2H); 7.57-7.59 (m, 2H) ppm; ${ }^{13} \mathrm{C}$ NMR $\left(100 \mathrm{MHz}, \mathrm{CDCl}_{3}\right) \delta 115.21$, 115.43, 116.38, 116.61, 116.81, 116.88, 121.78, 127.45, 127.52, 130.64, 132.16, 137.38, 139.14, 155.26, 157.61 ppm; GC-MS: $\mathrm{C}_{12} \mathrm{H}_{9} \mathrm{BrFN}, \mathrm{m} / \mathrm{z} 264.90(\mathrm{M})^{+}$. Anal. calcd for $\mathrm{C}_{12} \mathrm{H}_{9} \mathrm{BrFN}$ : C 54.16, H 3.41, N 5.26; found C 54.12, $\mathrm{H}$ $3.38, \mathrm{~N} 5.23$. 
3'-Chloro-5-ethyl-biphenyl-2-ylamine $4 \mathbf{4 f}{ }^{1} \mathrm{H}-\mathrm{NMR}\left(400 \mathrm{MHz}, \mathrm{CDCl}_{3}\right): \delta 1.21$ (t, 3H); 2.57 (q, 2H); 3.65 (brs, 2H); $6.70(\mathrm{~d}, J=8.1 \mathrm{~Hz}, 1 \mathrm{H}) ; 6.94(\mathrm{~m}, 1 \mathrm{H}) ; 7.00-7.02(\mathrm{~m}, 1 \mathrm{H}) ; 7.30-7.36(\mathrm{~m}, 3 \mathrm{H}) ; 7.46(\mathrm{~s}, 1 \mathrm{H}) \mathrm{ppm} ;{ }^{13} \mathrm{C}$ NMR $(100$ $\left.\mathrm{MHz}, \mathrm{CDCl}_{3}\right) \delta 15.88,27.92,115.97,126.17,127.17,127.27,128.36,129.21,129.62,129.96,134.57,134.65$, 141.08, 141.63 ppm; GC-MS: $\mathrm{C}_{14} \mathrm{H}_{14} \mathrm{ClN}, \mathrm{m} / \mathrm{z} 231.08(\mathrm{M})^{+}$. Anal. calcd for $\mathrm{C}_{14} \mathrm{H}_{14} \mathrm{ClN}$ : C 72.57, H 6.09, N 6.04; found C 72.50, H 6.05, N 6.01.

3'-Bromo-5-ethyl-biphenyl-2-ylamine 4g ${ }^{1} \mathrm{H}-\mathrm{NMR}\left(400 \mathrm{MHz}, \mathrm{CDCl}_{3}\right): \delta 1.22$ (t, 3H); 2.58 (q, 2H); 3.61 (brs, 2H); $6.72(\mathrm{~d}, J=8.1 \mathrm{~Hz}, 1 \mathrm{H}) ; 6.94(\mathrm{~m}, 1 \mathrm{H}) ; 7.01(\mathrm{dd}, J=2.2 \mathrm{~Hz}, J=8.1 \mathrm{~Hz}, 1 \mathrm{H}) ; 7.30(\mathrm{~m}, 1 \mathrm{H}) ; 7.33-7.46(\mathrm{~m}, 2 \mathrm{H}) ; 7.61$ $(\mathrm{m}, 1 \mathrm{H}) \mathrm{ppm} ;{ }^{13} \mathrm{C} \mathrm{NMR}\left(100 \mathrm{MHz}, \mathrm{CDCl}_{3}\right) \delta 15.88,27.92,115.97,122.82,126.08,127.73,128.39,129.63,130.10$, 130.24, 132.11, 134.68, 141.07 ppm; GC-MS: $\mathrm{C}_{14} \mathrm{H}_{14} \mathrm{BrN}, \mathrm{m} / \mathrm{z} 275.05(\mathrm{M})^{+}$. Anal. calcd for $\mathrm{C}_{14} \mathrm{H}_{14} \mathrm{BrN}$ : C $60.89, \mathrm{H}$ 5.11, N 5.07; found C 60.85, H 5.09, N 5.03.

4'-Fluoro-5-ethyl-biphenyl-2-ylamine $4 \mathbf{h}{ }^{1} \mathrm{H}-\mathrm{NMR}\left(400 \mathrm{MHz}, \mathrm{CDCl}_{3}\right): \delta 1.22$ (t, 3H); 2.58 (q, 2H); 3.61 (brs, 2H); $6.73(\mathrm{~d}, J=8.1 \mathrm{~Hz}, 1 \mathrm{H}) ; 6.93(\mathrm{~m}, 1 \mathrm{H}) ; 7.00(\mathrm{~m}, 1 \mathrm{H}) ; 7.10-7.14(\mathrm{~m}, 2 \mathrm{H}) ; 7.41-7.44(\mathrm{~m}, 2 \mathrm{H}) \mathrm{ppm} ;{ }^{13} \mathrm{C}$ NMR $(100$ $\left.\mathrm{MHz}, \mathrm{CDCl}_{3}\right) \delta 15.89,27.94,115.51,115.73,115.87,126.69,127.96,129.80,130.71,130.79,134.64,135.60$, 135.63, 141.18, 160.77, 163.22 ppm; GC-MS: $\mathrm{C}_{14} \mathrm{H}_{14} \mathrm{FN}, \mathrm{m} / \mathrm{z} 215.10(\mathrm{M})^{+}$. Anal. calcd for $\mathrm{C}_{14} \mathrm{H}_{14} \mathrm{FN}$ : C 78.11, $\mathrm{H}$ 6.56, N 6.51; found C 78.08, H 6.53, N 6.49.

4'-Bromo-5-ethyl-biphenyl-2-ylamine 4i ${ }^{1} \mathrm{H}-\mathrm{NMR}\left(400 \mathrm{MHz}, \mathrm{CDCl}_{3}\right): \delta 1.22(\mathrm{t}, 3 \mathrm{H}) ; 2.59$ (q, 2H); 3.96 (brs, $2 \mathrm{H}$ ); $6.74(\mathrm{~d}, J=8.0 \mathrm{~Hz}, 1 \mathrm{H}) ; 6.92(\mathrm{~d}, J=1.9 \mathrm{~Hz}, 1 \mathrm{H}) ; 7.02(\mathrm{dd}, J=1.9 \mathrm{~Hz}, J=8.0 \mathrm{~Hz}, 1 \mathrm{H}) ; 7.35(\mathrm{~m}, 2 \mathrm{H}) ; 7.56(\mathrm{~m}, 2 \mathrm{H})$ ppm; ${ }^{13} \mathrm{C}$ NMR $\left(100 \mathrm{MHz}, \mathrm{CDCl}_{3}\right) \delta 15.86,27.94,116.24,121.18,126.66,128.24,129.61,130.84,131.88,135.07$, 138.54, 140.54 ppm; GC-MS: $\mathrm{C}_{14} \mathrm{H}_{14} \mathrm{BrN}, \mathrm{m} / \mathrm{z} 275.05(\mathrm{M})^{+}$. Anal. calcd for $\mathrm{C}_{14} \mathrm{H}_{14} \mathrm{BrN}$ : C 60.89, H 5.11, N 5.07; found C 60.86, H 5.08, N 5.05.

The FT-IR of onion peels obtained from a local grocery shop (Figure 1a) and the onion peels which was sampled from a local waste disposal site (Figure 1b) were compared. In Figure 1, a broad band centred at $3393 \mathrm{~cm}^{-1}$ is assignable to the stretching vibration of hydroxyl groups. The absorption band at $1637 \mathrm{~cm}^{-1}$ is attributed to the stretching frequency of carbonyl groups. Comparison of the two spectra showed that the relative intensity, shapes and the stretching frequencies of all signals shown by spectrum Figure $1 \mathrm{~b}$ were well preserved as compared to that of FT-IR spectrum in Figure 1a. This indicated that no considerable changes were observed, in terms of the chemical structure (functional groups and hydrogen bonding network) on the onion peels which were obtained from the local grocery shop as compared to the recovered onion peels sampled from the local waste disposal site.

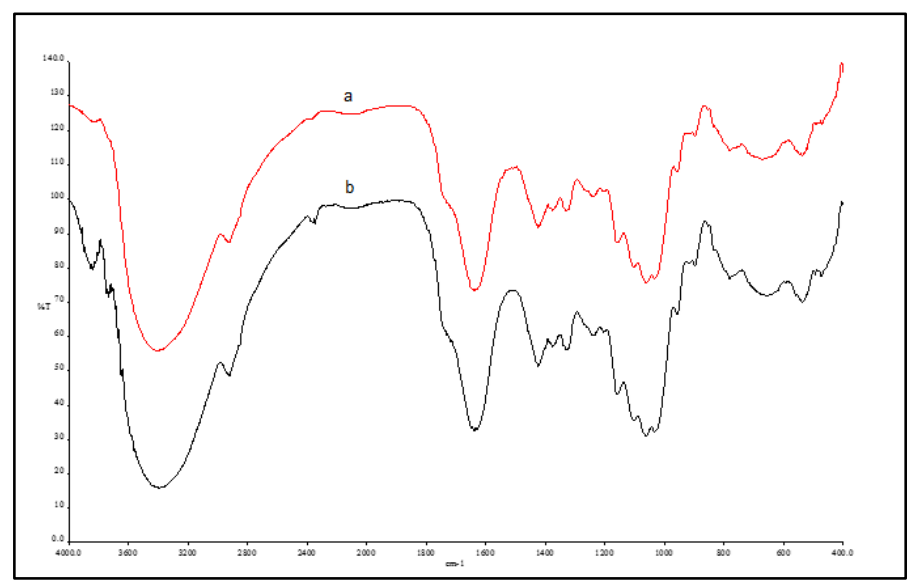

Figure 1. FTIR spectra of (a) onion peels obtained from a local grocery shop and (b) recovered onion peels from a local waste disposal site 
In the optimisation study, we first examined the model reaction by using 4-fluroaniline 1a as the model substrate. The arylation of $1 \mathbf{a}(10 \mathrm{mmol})$ with 3-chlorophenylhydrazine $3 \mathrm{a}$ in the presence of $0.5 \mathrm{~mL}$ of the WEOPA at $80{ }^{\circ} \mathrm{C}$ for 3 hours was investigated (Table 1). The regioselectivity of this reaction was found to produce $4 \mathbf{a}$ in poor yield (Table 1, entry 1). Control reaction by employing pure water as solvent did not yield the product 4a. (Table 1, entry 1) demonstrates the catalytic ability of WEOPA. As expected, a poor yield of $\mathbf{4 a}$ was observed if the reaction time was short (Table 1, entry 6). The use of $2.0 \mathrm{~mL}$ of WEOPA produced the maximum isolated yield of $4 \mathbf{a}(60 \%)$ (Table 1, entry 4). When the reaction mixture was heated for a longer period of time by using $2 \mathrm{~mL}$ of WEOPA at $80{ }^{\circ} \mathrm{C}$ (Table 1, entry 7), this did not further improve the yield of $4 \mathbf{a}$. The same results were observed when the temperature of the reaction was altered, which did not result in a better yield (Table 1, entries 8-9). With all these information in mind, the optimised condition was determined (Table 1, entry 4).

Table 1. The optimization study using 1a as the model substrate

\begin{tabular}{llccc}
\hline Entry & Solvent $(\mathbf{m L})$ & Time (h) & Temperature $\left({ }^{\circ} \mathbf{C}\right)$ & Yield $^{\text {a }}(\boldsymbol{\%})$ \\
\hline 1 & $\mathrm{H}_{2} \mathrm{O}(1.0)$ & 3 & 50 & 0 \\
2 & WEOPA $(0.5)$ & 3 & 80 & 46 \\
3 & WEOPA (1.0) & 3 & 80 & 50 \\
4 & WEOPA (2.0) & 3 & 80 & 60 \\
5 & WEOPA (3.0) & 3 & 80 & 58 \\
6 & WEOPA (2.0) & 1 & 80 & 30 \\
7 & WEOPA (2.0) & 4 & 80 & 56 \\
8 & WEOPA (2.0) & 3 & 100 & 56 \\
9 & WEOPA (2.0) & 3 & 60 & 45 \\
\hline
\end{tabular}

${ }^{\mathrm{a}}$ Isolated yield

Next, the general applicability of the WEOPA catalytic system to synthesise 2-aminobiaryls using different hydrazine's under the optimised condition was examined. In all the cases, the 2-aminobiaryls were obtained after silica gel column purification, with yields ranging from $47 \%$ to $60 \%$. As indicated in Table 2, all arylation reactions of 4-fluoroaniline 1 with electron-withdrawing groups $(\mathrm{Cl}, \mathrm{Br}$ and $\mathrm{F})$ favoured the reactions by affording the corresponding 2-aminobiaryls $\mathbf{4 a - 4 e}$ in moderate to good yields (Table 2, entries 1-5). 4-ethylaniline 2 was also subjected to the optimised reaction condition by reacting with electron-withdrawing groups $(\mathrm{Cl}, \mathrm{Br}$ and $\mathrm{F})$. The arylation employing $\mathbf{2}$ as the starting material proceeded smoothly to generate products in reasonably good yields within $3 \mathrm{~h}$ of reaction time (Table 2, entries 6-9). It is noteworthy that, compared to previous study, the catalytic performance of the WEOPA was regarded as unprecedented because of the fact that no solvents and additive were involved in the synthesis of 2-aminobiaryls [24-26]. In addition, all products were synthesised in a reasonable reaction time. The synthesized 2-aminobiaryls 4a-i were characterised by NMR $\left({ }^{1} \mathrm{H}\right.$ and $\left.{ }^{13} \mathrm{C}\right)$ and further supported by GC-MS analyses.

Furthermore, the WEOPA catalytic system showed promising utility in line with sustainable chemistry due to its reusability in the synthesis of $\mathbf{4}$ model reaction. Upon the completion of arylation reaction between 4-fluonoaniline and 3-chlorophenylhydrazine, the WEOPA catalytic system was recovered and reused for up to five times, without significant losses of catalytic activity as shown in Figure 2. 
Table 2. Isolated yields and the catalytic synthesis of 2-aminobiaryls 4

\begin{tabular}{lccccc}
\hline Entry & $\begin{array}{c}\text { Starting } \\
\text { Materials }\end{array}$ & $\mathbf{R}^{\mathbf{1}}$ & $\begin{array}{c}\text { Product } \\
\text { Reaction Time } \\
\text { (h) }\end{array}$ & $\begin{array}{c}\text { Isolated Yield } \\
(\%)\end{array}$ \\
\hline 1 & 1 & $3-\mathrm{Cl}$ & $4 \mathrm{a}$ & 3 & 60 \\
2 & 1 & $3-\mathrm{Br}$ & $4 \mathrm{~b}$ & 3 & 55 \\
3 & 1 & $3-\mathrm{F}$ & $4 \mathrm{c}$ & 3 & 56 \\
4 & 1 & $4-\mathrm{F}$ & $4 \mathrm{~d}$ & 3 & 50 \\
5 & 1 & $4-\mathrm{Br}$ & $4 \mathrm{e}$ & 3 & 49 \\
6 & 2 & $3-\mathrm{Cl}$ & $4 \mathrm{f}$ & 3 & 58 \\
7 & 2 & $3-\mathrm{Br}$ & $4 \mathrm{~g}$ & 3 & 53 \\
8 & 2 & $4-\mathrm{F}$ & $4 \mathrm{~h}$ & 3 & 51 \\
9 & 2 & $4-\mathrm{Br}$ & $4 \mathrm{i}$ & 3 & 47 \\
\hline
\end{tabular}

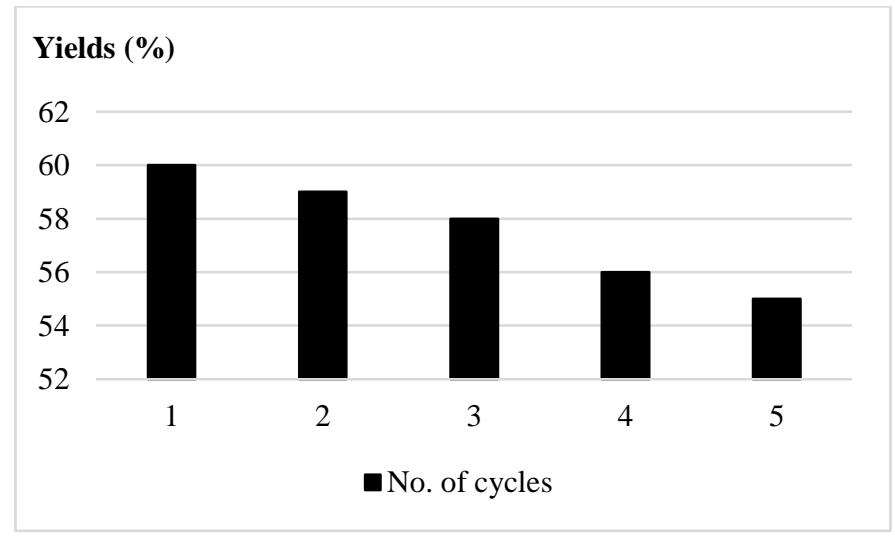

Figure 2. Recyclability of WEOPA in the synthesis of 2-aminobiaryls. Reaction conditions: 1 mmol of 3chlorophenylhydrazine, $10 \mathrm{mmol}$ of 4 -fluoroaniline, $2 \mathrm{~mL}$ of WEOPA, $80^{\circ} \mathrm{C}$

Next, the characterisation of the ash-water extract with Inductively Coupled Plasma-Optical Emission Spectroscopy (ICP-OES) produced the following results (reported as mean value \pm standard deviation) in parts per billion (ppb): potassium $(11749.00 \pm 227.00)$, sodium $(92.00 \pm 0.21)$, magnesium $(528.00 \pm 40.00)$, phosphorus $(87.00 \pm 5.00)$, yttrium $(33.00 \pm 0.02)$ and boron $(32.00 \pm 3.00)$. The data revealed that the ash-water extract primarily consisted of oxides, such as phosphorus, magnesium, zinc, manganese and sodium as major constituents along with other trace elements. We hypothesised that the alkali oxides, such as potassium, magnesium and calcium reacted with water to afford the hydroxides of these alkali and alkaline metals. These alkali and alkaline metals facilitated the formation of 2-aminobiaryls by acting as bases in the current investigated reaction, thus eliminated the use of external bases.

\section{Conclusion}

In the current study, we have demonstrated an efficient method of synthesizing 2-aminobiaryls catalyzed by the use of onion peel ash-water extract (WEOPA). There were several advantages of employing an ash-water extract catalytic system, including eliminating the use of additive, external bases and flammable solvent. Furthermore, the current catalytic system could be recovered and reused for up to five times, without significant losses of catalytic activity. We anticipate that the ash-water extract catalytic system could be used for the other organic transformations in the near future. 


\section{Acknowledgement}

The authors would like to acknowledge the Ministry of Higher Education (MOHE) for the research grant (FRGS 59292) and financial assistance and Universiti Malaysia Terengganu for research facilities provided.

1. Polshettiwar, V., Luque, R., Fihri, A., Zhu, H., Bouhrara, M. and Basset, J.-M. (2011). Magnetically recoverable nanocatalysts. Chemical Review, 111(5): 3036-3075.

2. Simon, M.-O. and Li, C.-J. (2012). Green chemistry oriented organic synthesis in water. Chemical Society Review, 41(4): 1415-1427.

3. Waseem, M. A., Srivastava, A., Srivastava, A. and Siddiqui, I. (2015). Water and ionic liquid synergy: A novel approach for the synthesis of benzothiazole-2 (3H)-one. Journal of Saudi Chemical Society, 19(3): 334-339.

4. Li, C.-J. and Chen, L. (2006). Organic chemistry in water. Chemical Society Review, 35(1): 68-82.

5. Wagare, D. S., Netankar, P. D., Shaikh, M., Farooqui, M. and Durrani, A. (2017). Highly efficient microwaveassisted one-pot synthesis of 4-aryl-2-aminothiazoles in aqueous medium. Environmental Chemistry Letters, 15(3): 475-479.

6. Noshiranzadeh, N., Emami, M., Bikas, R. and Kozakiewicz, A. (2017). Green click synthesis of $\beta$-hydroxy-1, 2, 3-triazoles in water in the presence of a $\mathrm{Cu}$ (II)-azide catalyst: a new function for $\mathrm{Cu}$ (II)-azide complexes. New Journal of Chemistry, 41(7): 2658-2667.

7. Banerjee, B. (2017). Recent developments on ultrasound assisted catalyst-free organic synthesis. Ultrasonics Sonochemistry, 35(2017): 1-14.

8. Miklós, F. and Fülöp, F. (2016). A simple green protocol for the condensation of anthranilic hydrazide with cyclohexanone and n-benzylpiperidinone in water. Journal of Heterocyclic Chemistry, 53(1): 32-37.

9. Yang, Y., Bao, Y., Guan, Q., Sun, Q., Zha, Z. and Wang, Z. (2017). Copper-catalyzed S-methylation of sulfonyl hydrazides with TBHP for the synthesis of methyl sulfones in water. Green Chemistry, 19(1): 112-116.

10. Sarmah, M., Mondal, M. and Bora, U. (2017). Agro-waste extract based solvents: emergence of novel green solvent for the design of sustainable processes in catalysis and organic chemistry. ChemistrySelect, 2(18): 5180-5188.

11. RekhaáBoruah, P. and AzizáAli, A. (2015). Pd (OAc) 2 in WERSA: a novel green catalytic system for SuzukiMiyaura cross-coupling reactions at room temperature. Chemical Communications, 51(57): 11489-11492.

12. Dewan, A., Sarmah, M., Bora, U. and Thakur, A. J. (2016). A green protocol for ligand, copper and base free Sonogashira cross-coupling reaction. Tetrahedron Letters, 57(33): 3760-3763.

13. Bagul, S. D., Rajput, J. D. and Bendre, R. S. (2017). Synthesis of 3-carboxycoumarins at room temperature in water extract of banana peels. Environmental Chemistry Letters, 15(4): 725-731.

14. Surneni, N., Barua, N. C. and Saikia, B. (2016). Application of natural feedstock extract: The Henry reaction. Tetrahedron Letters, 57(25): 2814-2817.

15. Saikia, B. and Borah, P. (2015). A new avenue to the Dakin reaction in $\mathrm{H}_{2} \mathrm{O}_{2}-$ WERSA. RSC Advances, 5(128): 105583-105586.

16. Choi, I. S., Cho, E. J., Moon, J.-H. and Bae, H.-J. (2015). Onion skin waste as a valorization resource for the by-products quercetin and biosugar. Food Chemistry, 188: 537-542.

17. Marshall, R. E. and Farahbakhsh, K. (2013). Systems approaches to integrated solid waste management in developing countries. Waste Managment, 33(4): 988-1003.

18. Nile, S. H. and Park, S. W. (2013). Total phenolics, antioxidant and xanthine oxidase inhibitory activity of three colored onions (Allium cepa L.). Frontier in Life Science, 7(3-4): 224-228.

19. Sharma, K., Mahato, N., Nile, S. H., Lee, E. T. and Lee, Y. R. (2016). Economical and environmentallyfriendly approaches for usage of onion (Allium cepa L.) waste. Food \& Function, 7(8): 3354-3369.

20. Gao, S., Li, L., Geng, K., Wei, X. and Zhang, S. (2015). Recycling the biowaste to produce nitrogen and sulfur self-doped porous carbon as an efficient catalyst for oxygen reduction reaction. Nano Energy, 16: 408-418.

21. Costantino, L. and Barlocco, D. (2006). Privileged structures as leads in medicinal chemistry. Current Medicinal Chemistry, 13(1): 65-85.

22. Jiang, H., Sun, J. and Zhang, J. (2012). A review on synthesis of carbazole-based chromophores as organic light-emitting materials. Current Organic Chemistry, 16(17): 2014-2025.

23. McGlacken, G. P. and Bateman, L. M. (2009). Recent advances in aryl-aryl bond formation by direct arylation. Chemical Society Review, 38(8): 2447-2464. 
24. Jiang, T., Chen, S.-Y., Zhang, G.-Y., Zeng, R.-S. and Zou, J.-P. (2014). CoPc-catalyzed selective radical arylation of anilines with arylhydrazines for synthesis of 2-aminobiaryls. Organic \& Biomolecular Chemistry, 12(35): 6922-6926.

25. Jiang, T., Chen, S.-Y., Zhuang, H., Zeng, R.-S. and Zou, J.-P. (2014). Air-promoted direct radical arylation of anilines with arylhydrazines. Tetrahedron Letters, 55(33): 4549-4552.

26. Chen, Z.-X. and Wang, G.-W. (2005). One-pot sequential synthesis of acetoxylated [60] fullerene derivatives. Journal of Organic Chemistry, 70(6): 2380-2383. 